\title{
PERAN AUDITOR EKSTERNAL DALAM MENINGKATKAN KEPATUHAN PEMBAYARAN PAJAK DAERAH
}

\author{
Gati Reditya Saputro \\ Prodi Akuntansi - Fakultas Ekonomi dan Bisnis \\ Universitas Muhammadiyah Yogyakarta \\ gati@umy.ac.id
}

\begin{abstract}
ABSTRAK
Penelitian ini menjelaskan fungsi pihak ketiga yaitu auditor eksternal dalam membantu pemerintah meningkatkan kepatuhan pembayaran pajak. Tujuan penelitian ini adalah untuk mengetahui peran auditor eksternal dalam pemeriksaan pajak terhadap peningkatan tingkat kepatuhan Wajib Pajak Hotel dan Restoran pada Kabupaten Sleman dan Kota Yogyakarta di Provinsi Daerah Istimewa Yogyakarta. Metode yang digunakan dalam penelitian ini adalah pendekatan kualitatif dengan melakukan wawancara kepada auditor eksternal dan pegawai dinas pendapatan daerah instansi terkait untuk mencapai tujuan penelitian. Hasil penelitian yang bersifat interpretatif meyakini bahwa pengaruh pemeriksaan dilakukan akibat sifat independensi auditor, sanksi yang diberlakukan dan standar pemeriksaan dalam hal pola perilaku yang berkualitas efisiensi wajib pajak yang dalam melaporkan omzet perpajakan. Lebih lanjut lagi, pendekatan edukatif yang dilakukan oleh auditor eksternal mampu memperbaiki perilaku wajib pajak. Penelitian ini perlu pengembangan subjek penelitian dengan menambah sampel auditor eksternalpada KAP besar dan KAP kecil di berbagai daerah.
\end{abstract}

Kata Kunci : Auditor eksternal; kepatuhan pajak; pemeriksaan pajak; self-assesment system

\begin{abstract}
This study explains the need of regional government engangement with third party, external auditors, to participate and intensify tax compliance. The study aims to obtain role of auditor external which examine tax payers compliance in accordance toincrease hotels and restaurants tax revenue in Kabupaten Sleman and Kotamadya Yogyakarta, Daerah Istimewa Yogyakarta Province. Method using qualitative research with interview conducted to external auditor and government worker to reach the goal. Interpretative results believed that external auditor tax examination according to independency, sanction, and standard auditing carried out perceived good quality of efficiency and tax payers behavior in the case of reporting their revenues. Moreover, educative approaches afforded by external auditors capable to change tax payers perceived into better behaviour taxe payers to pay taxes..
\end{abstract}

Keywords: auditor external; tax compliance; tax examination; selfassessment system

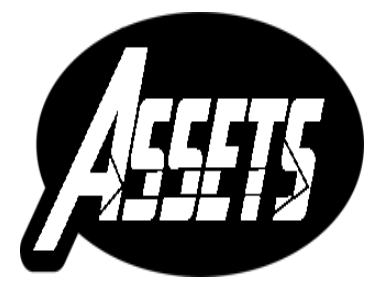

ASSETS

Jurnal Akuntansi dan Pendidikan

Vol. 6 No. 2

Hlmn. 117-129

Madiun, Oktober 2017 p-ISSN: 2302-6251

e-ISSN: 2477-4995

Artikel masuk: 9 Agustus 2017 Tanggal diterima: 25 Oktober 2017 


\section{PENDAHULUAN}

Dalam suatu pemerintahan daerah, pajak hotel dan restoran merupakan salah satu pendapatan yang signifikan bagi Pendapatan Asli Daerah (PAD). Banyaknya Hotel dan Restoran merupakan salah satu jenis pelayanan jasa pendukung sebagai penyedia tempat inap sementara dan makanan bagi wisatawan. Pajak Hotel dan Restoran menyumbang 23,22 persen Pendapatan Asli Daerah di Kabupaten Sleman dan mampu meningkatkan penerimaan sebesar rata-rata 4.07\% dengan kenaikan Pajak Hotel Restoran sebesar 2,53\% setiap tahunnya sejak 1994 s/d 2000 (Arini, 2016). Di Kota Yogyakarta, Pajak Hotel dan Restoran (PHR) meyumbang 30\% Pendapatan Asli Daerah untuk membiayai program-program pemerintah daerah (Putri, 2016). Pengertian pajak umum berhubungan dengan tugas negara yang menyelenggarakan pemerintahan. Menurut Prof. Dr. Rochmat Soemitro, SH (dalam Mardiasmo, 2006:1) Pajak adalah iuran rakyat kepada kas negara berdasarkan Undang-undang (yang dapat dipaksakan) dengan tiada mendapat jasa timbal (kontraprestasi) yang langsung dapat ditujukan dan yang digunakan untuk membayar pengeluaran umum.

Menurut R. Santoso Brotodiharjo, Pajak adalah iuran kepada negara yang dapat dipaksakan yang terutang oleh membayarnya menurut peraturan-peraturan, dengan tidak mendapat prestasi-kembali, yang langsung dapat ditujukan dan gunanya adalah untuk membiayai pengeluaran-pengeluaran umum berhubungan dengan tugas negara yang menyelenggarakan pemerintahan (Wirawan, 2002:4). Sedangkan menurut Mardiasmo, 2006:1 Fungsi pajak dapat dibagi menjadi 2, yaitu:

1. Fungsi penerimaan (budgetair). Pajak sebagai sumber dana penerimaan untuk membiayai pengeluaran-pengeluarannya. Contoh: dana yang dikumpulkan dari hasil pajak digunakan untuk membangun fasilitas-fasilitas umum.

2. Fungsi mengatur (regulerend). Pajak sebagai alat untuk mengatur atau melaksanakan kebijakan pemerintah dalam bidang sosial dan ekonomi. Contoh: Pajak yang tinggi dikenakan terhadap minuman keras untuk mengurangi konsumsi minuman keras, pajak yang tinggi dikenakan terhadap barang mewah untuk mengurangi gaya hidup konsumtif.

Direktorat Jendral Perimbangan Keuangan (Departemen Keuangan Republik Indonesia) sebagai bagian dari perumusan pajak daerah dan retribusi daerah, mensyaratkan beberapa kriteria objek yang menjadi pajak daerah, yaitu:

1. Pajak daerah bersifat pajak, bukan retribusi;

2. Objek pajak terletak atau terdapat di wilayah daerah kabupaten kota yang bersangkutan dan mempunyai mobilitas cukup rendah serta hanya melayani masyarakat di wilayah daerah kabupaten/kota yang bersangkutan;

3. Objek dan dasar pengenaan pajak tidak bertentangan dengan kepentingan umum;

4. Potensinya memadai. Hasil penerimaan pajak harus lebih besar dari biaya pemungutan;

5. Tidak memberikan dampak ekonomi yang negatif. Pajak tidak mengganggu alokasi sumber-sumber ekonomi dan tidak merintangi arus sumber daya ekonomi antar daerah maupun kegiatan ekspor-impor;

6. Memperhatikan aspek keadilan dan kemampuan masyarakat;

7. Menjaga kelestarian lingkungan, yang berarti bahwa pengenaan pajak tidak memberikan peluang kepada pemda atau Pemerintah atau masyarakat luas untuk merusak lingkungan.

Berdasarkan UU Perpajakan yang dikeluarkan Direktorat Jenderal Perimbangan

Keuangan (Departemen Keuangan Republik Indonesia). Jenis-jenis Pajak Daerah terbagi menjadi 2, yaitu: 
1. Pajak Provinsi meliputi: Pajak Kendaraan Bermotor dan Kendaraan di Atas Air, Bea Balik Nama Kendaraan di Atas Air, Pajak Bahan Bakar Kendaraan Bermotor; dan Pajak Pengambilan dan Pemanfaatan Air Bawah dan Air Permukaan.

2. Pajak Kabupaten/Kota meliputi: Pajak Hotel, Pajak Restoran, Pajak Hiburan, Pajak Reklame, Pajak Penerangan Jalan, Pajak Pengambilan Bahan Galian Golongan C, dan Pajak Parkir.

Besarnya tarif, untuk pajak provinsi ditetapkan secara seragam di seluruh Indonesia sebagaimana diatur dalam PP No. 65 Tahun 2001. Besarnya tarif definitif untuk pajak kabupaten/kota ditetapkan dengan Peraturan Daerah (Perda), namun tidak boleh lebih tinggi dari tarif maksimum yang telah ditentukan dalam UU.

Meskipun demikian target pendapatan pemerintah daerah dengan realisasi penerimaan pendapatan asli daerah sering kali tidak sesuai (sumber: Dinas Pendapatan Kabupaten Sleman dan Kota Yogyakarta, 2013). Target yang dicanangkan oleh pemerintah daerah tidak diimbangi dengan kemampuan pemerintah untuk melaksanakan pemungutan pajak secara efisien. Bukti otentik bahwa realisasi pendapatan daerah yang selalu di bawah angka yang ditargetkan menunjukkan ketidaksesuaian persepsi masyarakat terhadap kewajiban membayar pajak. Peran pemerintah/lembaga daerah yang bertanggungjawab atas pemungutan pajak daerah perlu dievaluasi apakah pemerintah daerah telah melaksanakan tugas yang dibebankan secara profesional? Dalam hal ini, pemerintah daerah dan auditor eksternal menekankan pentingnya pemeriksaan pajak daerah dalam meningkatkan pendapatan daerah untuk menunjang kegiatan pemerintah daerah pada khususnya terhadap pencapaian tujuan negara.

Beberapa pendekatan yang dilakukan untuk meningkatkan pendapatan pajak daerah salah satunya dengan memerintahkan auditor eksternal untuk melakukan pemeriksaan pajak yang sesuai dengan ketentuan yang tercantum pada undangundang dan standar pemeriksaan yang berlaku sesuai dengan Standar Pemeriksaan Keuangan Negara (Peraturan BPK Nomor 01 Tahun 2007) menimbang untuk melaksanakan Pasal 5 ayat (1) Undang-Undang Nomor 15 Tahun 2004 tentang Pemeriksaan dan Pengelolaan Tanggung Jawab Keuangan Negara, Pasal 9 ayat (1) huruf e dan Pasal 31 ayat (2) Undang-Undang Nomor 15 Tahun 2006 tentang Badan Pemeriksa Keuangan, mengingat Undang-Undang Nomor 17 Tahun 2003 tentang Keuangan Negara (Lembaran Negara Republik Indonesia Tahun 2003 Nomor 47, Tambahan Lembaran Negara Republik Indonesia Nomor 4286), dan sesuai dengan amanat Pasal 23 (1) E UUD 1945 yang menyatakan untuk memeriksa pengelolaan dan tanggung jawab tentang Keuangan Negara.

Pemeriksaan adalah proses identifikasi masalah, analisis, dan evaluasi yang dilakukan secara independen, objektif, dan profesional berdasarkan standar pemeriksaan, untuk menilai kebenaran, kecermatan, kredibilitas, dan keandalan informasi mengenai pengelolaan dan tanggung jawab keuangan negara. (SPKN No.1 Tahun 2007:Ps.1). Pemeriksaan ini berlaku untuk semua pemeriksaan yang dilaksanakan terhadap entitas, program, kegiatan serta fungsi yang berkaitan dengan pelaksanaan pengelolaan dan tanggung jawab Keuangan Negara dengan peraturan perundang-undangan. Setiap pemeriksaan dimulai dengan penetapan tujuan dan penentuan jenis pemeriksaan yang akan dilaksanakan serta standar yang harus diikuti oleh pemeriksa. Menurut SPKN, Standar Pemeriksaan ini terbagi dalam beberapa jenis yaitu:

1. Pemeriksaan Keuangan

Pemeriksaan Keuangan adalah pemeriksaan atas laporan keuangan. Pemeriksaan ini bertujuan untuk memberikan keyakinan yang memadai (reasonable 
assurance) apakah laporan keuangan telah disajikan secara wajar, dalam semua hal yang material sesuai dengan prinsip akuntansi yang berlaku umum di Indonesia atau basis akuntansi komprehensif selain prinsip akuntansi yang berlaku umum di Indonesia.

2. Pemeriksaan Kinerja

Pemeriksaan Kinerja adalah pemeriksaan atas pengelolaan keuangan negara yang terdiri atas pemeriksaan aspek ekonomi dan efisiensi serta pemeriksaan aspek efektivitas. Pemeriksaan ini juga menguji kepatuhan terhadap ketentuan peraturan perundang-undangan serta pengendalian intern. Tujuan pemeriksaan yang menilai hasil dan efektivitas suatu program adalah mengukur sejauh mana suatu program mencapai tujuannya. Tujuan pemeriksaan yang menilai ekonomi dan efisiensi berkaitan dengan apakah suatu entitas telah menggunakan sumber dayanya dengan cara yang paling produktif di dalam mencapai tujuan.

3. Pemeriksaan Dengan Tujuan Tertentu

Pemeriksaan Dengan Tujuan Tertentu bertujuan untuk memberikan simpulan atas suatu hal yang diperiksa. Pemeriksaan Dengan Tujuan Tertentu dapat bersifat: eksaminasi (examination), reviu (review), atau prosedur yang disepakati (agreed-upon procedures). Pemeriksaan dengan tujuan tertentu meliputi antara lain pemeriksaan atas hal-hal lain di bidang keuangan, pemeriksaan investigatif, dan pemeriksaan atas sistem pengendalian intern. Apabila pemeriksa melakukan pemeriksaan dengan tujuan tertentu berdasarkan permintaan, maka pemeriksa harus memastikan komunikasi tertulis yang memadai bahwa sifat pemeriksaan dengan tujuan tertentu adalah telah sesuai dengan permintaan.

Standar Pemeriksaan Keuangan Negara (SPKN) adalah patokan untuk melakukan pemeriksaan pengelolaan dan tanggung jawab keuangan negara. Auditor eksternal adalah pemeriksa seperti yang tercantum pada Standar Pemeriksaan Keuangan Negara pasal 6 "Akuntan Publik atau pihak lainnya yang melakukan pemeriksaan atas pengelolaan dan tanggung jawab Keuangan Negara sesuai dengan peraturan perundang-undangan."

Auditor eksternal mempunyai peran yang kuat dalam melakukan pemeriksaan terhadap wajib pajak yang melaporkan laporan keuangan (disclosure). Ojo (2009) menyatakan bahwa auditor eksternal berperan untuk memastikan bahwa peraturan (dalam peristiwa kebijkan akuntansi) telah dilaksanakan dan berkontribusi terhadap peningkatan Corporate Governance. Selanjutnya, auditor eksternal mempunyai tanggungjawab dalam membantu pemerintah meningkatkan corporate governance yang tercermin dari peningkatan penerimaan pajak daerah.

Self assessment system merupakan suatu sistem pemungutan pajak yang memberi wewenang Wajib Pajak untuk menentukan sendiri jumlah pajak yang terutang setiap tahunnya sesuai dengan Ketentuan Perundang-Undangan Perpajakan (UU KUP) Republik Indonesia. Dalam prinsip self assesment system, telah mengubah paradigma pajak selama ini sehingga pembayaran pajak tidak lagi dianggap sebagai beban melainkan sebuah tugas kenegaraan yang harus dilaksanakan. Upaya pemberdayaan masyarakat melalui sistem ini perlu diikuti tindakan pengawasan guna mewujudkan tercapainya sasaran penerimaan pajak daerah.

Sikap didefinisikan sebagai perasaan mendukung atau memihak (favorableness) atau perasaan tidak mendukung atau tidak memihak (unfavorableness) terhadap suatu objek yang akan disikapi. Perasaan ini timbul dari adanya evaluasi individu atas keyakinan terhadap hasil yang didapatkan dari perilaku tersebut. (Ajzen, 1991). Sikap juga menunjukkan tingkatan dimana seseorang mempunyai evaluasi yang baik atau kurang baik tentang perilaku yang dihadapi. 
Pengujian teori persepsian pembayaran pajak berdasarkan Theory of Planned Behaviour menghasilkan tiga hal yang mendasari wajib pajak untuk membayar pajak yaitu: persepsi kekayaan dalam peraturan perpajakan, harapan normatif terhadap kepatuhan, dan besarnya denda yang diterima (Efebera, 2006). Terdapat juga hubungan dua arah antara denda yang diterima dengan pertukaran kekayaan, dan denda yang diterima dengan harapan normatif.

Theory of Planned Behaviour merupakan teori yang dikemukakan oleh Ajzen, modifikasi dari teori Theory of Reasoned Action yang didesain untuk memprediksi pola perilaku yang mendasari seseorang melakukan sesuatu dan mengetahui psikologi determinan yang terjadi pada suatu tindakan. Ajzen (1991) menyatakan dalam Teori Perilaku Rencanaan (Theory of Planned Behaviour) bahwa perilaku individu dipengaruhi oleh niat, sedangkan niat untuk berperilaku dipengaruhi oleh variabel sikap (attitude), norma subjektif (subjective norms) dan perilaku kontrol persepsian (perceived behaviour control).

Teori Tindakan Berasalan/Theory of Reasoned Action mengungkap tahap awal perilaku (behaviour) ditentukan oleh niat (intention). Pada tahap selanjutnya niat dapat dijelaskan dalam bentuk sikap-sikap terhadap perilaku (attitude towards behaviour) dan norma-norma subjektif (subjective norms). Pada tahap selanjutnya, sikap-sikap (attitude) dan norma-norma subyektif (subjective norms) dalam bentuk kepercayaan-kepercayaan tentang konsekuensi melakukan perilakunya dan tentang ekspektasi-ekspektasi normatif dari orang yang direferensi (referent) yang relevan (Hartono, 2008).

Pemerintah berupaya meningkatkan pendapatan dari sektor pajak melalui upaya-upaya pemberantasan mafia pajak. Sedangkan menurut Desai \& Dharmapala (2006) terdapat hubungan antara corporate governance dengan penghindaran pajak yang dilakukan perusahaan. Perusahaan cenderung dinilai sehat jika membayar pajak yang lebih sedikit dibandingkan dengan besarnya biaya utang yang ditanggung perusahaan. Padahal pemerintah berusaha meningkatkan pendapatan asli daerah dengan memperbaiki sistem pajak daerahnya akibat dari pola pembayaran pajak oleh perusahaan. Berdasarkan latar belakang masalah maka penulis meneliti tingkat kepatuhan wajib pajak hotel dan restoran pada Dinas Pendapatan Daerah (Dispenda) Kotamadya Yogyakarta \& Kabupaten Sleman pertanyaan penelitian yaitu bagaimana sikap kepatuhan wajib pajak ketika auditor eksternal melakukan pemerikasaan dengan mendampingi pemerintah dinas pendapatan daerah.

Dalam penelitian ini penulis mengharapkan adanya peningkatan kepatuhan pembayaran pajak yang dilakukan wajib pajak hotel dan restoran, khususnya pada dinas pendapatan daerah Kotamadya Yogyakarta \& Kabupaten Sleman sehubungan dengan pentingnya penerimaan pajak untuk meningkatkan pendapatan asli daerah (PAD). Peneliti tidak memungkiri bahwa ekspektasi masyarakat selaku shareholder terhadap penerimaan pajak daerah untuk memenuhi kepentingan publik sangatlah besar. Berdasarkan pada hal itu, peneliti ingin berkontribusi terhadap keputusan yang diambil oleh pemerintah melalui penelitian ini.

\section{METODE PENELITIAN}

\section{Tipe Penelitian}

Metode yang digunakan dalam penelitian ini adalah menggunakan kualitatif untuk mencapai tujuan penelitian. Dalam hal ini pengujian persepsian wajib pajak terhadap niat (intention) bayar pajak menggunakan persepsi kekayaan dalam peraturan perpajakan, harapan normatif terhadap kepatuhan, dan besarnya denda yang diterima untuk menilai niat wajib pajak melunasi beban pajak yang ditanggung 
perusahaan. Selanjutnya, niat wajib pajak membayar pajak akan tercermin dari kepatuhan mereka untuk membayar pajak. (Benk dkk, 2011).

Paradigma yang digunakan dalam penelitian ini adalah interpretavisme. Paradigm interpretatif yang melihat realita sebagai subjektivitas yang tergantung dari apa yang orang interpretasikan. Hal ini tercipta dari pemikiran seseorang yang kemudian menimbulkan pengetahuan yang diketahui sehingga orang itu sendiri yang akan menjadi pemrakarsa bagi dunianya dan mereka juga yang memaknai dunia yang dia ciptakan. Berdasarkan hal tersebut, tujuan dari riset ini adalah untuk memahami kehidupan sosial dan arti makna dari pemahaman tersebut. (Sarantakis, 1995)

Peneliti menggunakan desain studi kasus secara interpretatif karena pengambilan data sekunder laporan auditor eksternal tidak mudah didapatkan. Laporan audit independen adalah salah satu bentuk laporan yang dimiliki oleh peminta jasa, sehingga aksesabilitas pemerolehan data tersebut dibatasi. Studi ini merupakan model eksplorasi yang mendalam dari sebuah sistem yang terikat (bounded). Penelitian ini mendasarkan pengambilan data dengan cara ekstensif dari suatu peristiwa, proses yang berlangsung atau kejadian individual (Creswell, 2005).

\section{Teknik Pengumpulan Data}

Data menggunakan data primer dengan responden yang diwawancara adalah (1) anggota dinas pendapatan daerah yang berhubungan dengan penerimaan pajak hotel dan restoran di wilayah dinas pendapatan daerah Kotamadya Yogyakarta dan Kabupaten Sleman. (2) auditor eksternal yang melakukan pemeriksaan langsung kepada wajib pajak hotel dan restoran atas permintaan dari dinas pendapatan daerah, sehingga auditor eksternal di sini merupakan pihak ketiga.

\section{HASIL PENELITIAN DAN PEMBAHASAN \\ Auditor Eksternal}

Berdasarkan analisis auditor eksternal yang melakukan pemeriksaan, mereka melakukan pemeriksaan berdasarkan standar perpajakan yang berlaku pada ranah daerah yang melingkupinya. Penulis mewawancara seorang audior dengan posisi Auditor Senior dan telah mengaudit penerimaan pajak hotel dan restoran di lingkup dinas pendapatan daerah Kotamadya Yogyakarta dan Kabupaten Sleman paling tidak selama tiga (3) tahun.

Setelah mendapatkan peraturan perpajakannya, auditor melakukan standar pemeriksaan berdasarkan Institut Akuntan Publik Indonesia untuk menjalankan jasa atestasinya yaitu audit khusus.

"dahulu perusahaan " $X$ " ini pernah tidak melaporkan pajak sehingga menimbulkan kurang bayar pajak yang sangat besar. Lalu setelah dilakukan pemeriksaan dan diketahui adanya kurang bayar, mereka dikenai pasal dan aturan untuk melakukan pembayaran angsuran kurang bayar selama 10 tahun. Setelah diketahuinya pajak kurang bayar tersebut, wajib pajak menjadi lebih tertib dan patuh terhadap pajak. Namun tidak menjamin bahwa perusahaan akan membayar semua pajaknya sesuai ketentuan"

Keadaan yang dialami oleh auditor "Paijo" (bukan nama sebenarnya) telah disyaratkan dalam peraturan perpajakan baik dari peraturan pemerintah maupun pemerintah daerah. Terdapat beberapa elemen lingkungan yang dapat mempengaruhi akuntansi, salah satu diantaranya adalah perpajakan. Temuan kerugian negara/daerah akibat perbuatan melawan hukum baik sengaja maupun lalai karena adanya unsur ketidakpatuhan terhadap ketentuan perundang-undangan yang dapat berupa pemborosan dan kebocoran hingga korupsi. Adanya kasus-kasus di atas merupakan salah satu indikator rendahnya pengawasan pemerintah daerah dalam upaya 
memperoleh pendapatan daerah yang pada akhirnya akan berpengaruh perlambatan pembangunan daerah dan nasional.

Wajib Pajak dibedakan menjadi dua tipe, yang pertama adalah wajib pajak perorangan dengan rasio perputaran bisnis yang relatif kecil. Wajib pajak perorangan juga menanggung biaya gaji karyawan dan biaya operasional yang sangat tinggi. Namun hal tersebut sebetulnya tidak berkorealasi langsung dengan adanya peraturan perpajakan yang sifatnya lebih kaku. Kedua, adalah wajib pajak badan dengan sistem operasional yang lebih maju dan persyaratan administrasi yang lebih rumit. Wajib pajak badan ini mempunyai risiko yang lebih besar daripada WP perorangan, namun memiliki mitigasi sistem operasional juga yang lebih baik sehingga risiko bisnisnya cenderung lebih kecil.

"dari 20 wajib pajak baik perorangan maupun badan yang terdaftar sebagai wajib pajak hotel dan restoran, 4 wajib pajak hotel dan 5 wajib pajak restoran dinyatakan disclaimer. Artinya, wajib pajak tersebut tidak memiliki laporan keuangan yang komprehensif sehingga tidak ada laporan perpajakan yang transparan. Wajib pajak yang dinyatakan disclaimer semuanya adalah wajib pajak perorangan.

Peraturan daerah dengan peraturan diatasnya (Undang-Undang) seringkali juga menimbulkan interpretasi yang tidak sama diantara wajib pajak. Alih-alih spesifikasi yang tidak sama antar daerah pada propinsi-propinsi di Indonesia dapat menimbulkan perbedaan persepsi antara wajib pajak satu dengan wajib pajak yang lain. Masalah pembayaran zakat dan pembayaran pajak merupakan hal yang berbeda yang tidak dapat dicampuraduk. Tiap wajib pajak diperbolehkan memilih akan membayar zakat atau tidak, namun pembayaran pajak adalah kewajiban bernegara.

Permasalahan timbul ketika wajib pajak tidak melakukan pembayaran pajak dengan dalih sudah membayar pajak, sedangkan masyarakat pada umumnya juga tidak ingin dirugikan dengan adanya dualisme peraturan yang memperbolehkan pengurangan pembayaran pajak dari pembayaran zakat apalagi dilakukan dengan tidak sesuai rantai aturan pemerintah yang berlaku.

"Terdapat WP pribadi jenis usaha restoran yang tidak melaporkan pajak sebagaimana mestinya karena alasan sudah melakukan pembayaran zakat, namun bukti pembayaran zakat tidak dilampirkan. Padahal WP ini memiliki omzet yang besar terhadap PAD Kabupaten Sleman. Pelaporan penjualan/omzet berbeda dengan SPT yang disampaikan ke Dinas Pendapatan Daerah"

Beberapa sikap yang dilakukan oleh wajib pajak tersebut merupakan cermin dari bauran budaya yang terbentuk sejak masa lalu hingga akhirnya muncul pada saat sekarang. Hal ini perlu disikapi dengan pendekatan sosial kekeluargaan karena latar belakang ekonomi dan budaya yang terbentuk merupakan budaya kekeluargaan yang sudah ada sejak zaman dahulu. Perkembangan nilai-nilai akuntansi maupun perpajakan juga akan terkena dampak dari adanya kultur dan kebiasaan masyarakat yang telah melekat sejak dulu.

\section{Pemeriksa dari Dinas Pendapatan Daerah}

Pemeriksaan pajak dalam meningkatkan kepatuhan wajib pajak orang pribadi pada KPP Pratama Jakarta Sawah Besar Satu. Penelitian ini menitikberatkan pada pemeriksaan pajak terhadap kepatuhan Wajib Pajak Orang Pribadi dalam melaporkan pendapatannya (self-assesment). Hasilnya memberi keyakinan bahwa semakin tinggi tingkat pemeriksaan pajak maka semakin meningkat tingkat kepatuhan Wajib Pajak Orang Pribadi. (Anjarini dkk; 2012). Analisis Kontribusi Pajak Daerah menunjukkan pelaksanaan pemungutan Pajak Daerah di Kota Padang dilakukan sebagai bentuk tanggung jawab pemerintah daerah dalam upaya peningkatan pendapatan asli daerah 
diharapkan mampu mendukung rencana pemerintah jangka menengah maupun rencana jangka panjang. Dari analisa yang dilakukan dihasilkan peningkatan PAD pajak mulai tahun 2007 sampai dengan 2011. Persentase rata-rata kenaikan tiap tahun sebesar 0,87\% pertahun. (Wahyudi dkk; 2013)

Berdasar pada penelitian sebelumnya, penulis tertarik untuk mengangkat tema yang sama yaitu upaya peningkatan pajak daerah dengan melakukan wawancara kepada Pegawai Dinas Pendapatan Daerah dan Auditor Eksternal untuk menggambarkan deskripsi fenomena yang terjadi. Penulis melakukan wawancara kepada Auditor Eksternal terlebih dahulu sebagai objek penelitian karena pihak ketiga (auditor eksternal) mempunyai independensi dan netralitas yang lebih tinggi dibandingkan dengan pemerintah daerah selaku pelaksana pemeriksaan pajak. Penulis melakukan wawancara terhadap audior yang memiliki kompeten dalam melakukan audit dengan minimal memiliki pengalaman pemeriksaan terhadap penerimaan pajak hotel dan restoran di lingkup dinas pendapatan daerah Kotamadya Yogyakarta dan Kabupaten Sleman selama minimal 3 tahun.

Informasi kemudian dieksplorasi lebih lanjut dari petugas di dinas lingkungan pemerintah daerah dengan narasumber Ibu Titin selaku Kepala Bidang Pengembang PAD Kabupaten Sleman dan Bapak Y (tidak ingin disebutkan nama) selaku Kepala Bidang Pengembang PAD Kotamadya Yogyakarta. Kebutuhan sumberdaya dengan perencanaan pajak yang efisien dan terfokus merupakan kunci dari sukses atau tidaknya pola sistematika pembayaran pajak di wilayah daerah. Kurangnya komitmen dan independensi pegawai dinas pendapatan daerah dapat menyebabkan rendahnya tingkat kemampuan pemeriksaan wajib pajak dalam upaya melakukan pengumpulan pajak daerah.

"Peran auditor eksternal dapat membantu dinas pendapatan daerah dalam pemeriksaan dan menemukan temuan kurang bayar audit. Standar dan aturan pemeriksaan merupakan pendekatan yang lain yang dilakukan oleh auditor eksternal yang membuat wajib pajak lebih patuh membayar pajak".

Setelah dilakukan pemeriksaan pajak oleh auditor eksternal, pelaporan wajib pajak menjadi lebih patuh kemudian berdampak positif terhadap penerimaan pajak daerah, hanya saja sikap auditor eksternal yang melakukan audit ini dirasa oleh dinas pendapatan daerah tidak cukup efektif untuk membuat wajib pajak jera dan segera melakukan perbaikan sistematika pelaporan keuangan.

"Setelah auditor eksternal tidak melakukan pemeriksaan, perilaku wajib pajak ini kembali pada perilaku lama, yaitu tidak melaporkan semua transaksi yang seharusnya menjadi objek pajak untuk penerimaan pajak".

Pemeriksaan dan pengawasan keuangan daerah terhadap kinerja penyelenggaraan daerah mempunyai dampak yang baik. Pengawasan ekstern yang dilakukan oleh masyarakat terkait kelemahan sistem pengendalian intern, ketidakpatuhan terhadap ketentuan perundang-undangan, dan tindak lanjut atas temuan pemeriksaan yang sesuai dengan rekomendasi yang digunakan dengan baik oleh pemerintah daerah sebagai sarana perbaikan kinerja penyelenggaraan pemerintah daerah yang akan datang.

Berpartisipasi dalam organisasi dianggap memungkinkan adanya rasa diperlakukan secara adil, sehingga mendorong individu untuk meningkatkan motivasi individu dalam melakukan pembayaran pajak (Wisnu, 2016).

"Temuan auditor eksternal mampu mengungkap ketidakwajaran laporan yang dimiliki wajib pajak yang menyebabkan tidak patuhnya pembayaran pajak. Hampir semua wajib pajak perorangan dinyatakan disclaimer". 
Di sisi lain, pemerintah daerah yang menerapkan peraturan pemerintah (PP) tidak menjalankan sendiri peraturan yang telah dibuatnya. Hal ini dapat menimbulkan ketidakkonsistenan penerapan antara wajib pajak yang satu dengan wajib pajak yang lainnya. Wajib pajak sering kali merasa diperlakukan tidak adil akibat perlakuan berbeda terhadap hukum pajak oleh pemerintah daerah. Peraturan yang diatasnya menyebabkan perbedaan persepsi yang diterima wajib pajak (Widodo, 2010).

"Wajib pajak menganggap peraturan pemerintah dapat diimplementasikan ke peraturan daerah, dimana zakat merupakan objek pajak yang boleh dikurangkan dari objek pajak yang seharusnya dilaporkan. Hal ini dianggap oleh wajib pajak sebagai peluang penghindaran objek pajak sehingga wajib pajak tidak melaporkan pajak karena telah melakukan pembayaran zakat"

Beberapa penelitan menyatakan bahwa pemeriksaan yang dilakukan kepada Wajib Pajak Orang Pribadi secara statistik mempunyai pengaruh/hubungan positif signifikan dengan peningkatan pajak daerah (Anjarini dkk; 2012). Berdasar hasil penelitian mereka dapat dikatakan bahwa pemeriksaan pajak yang dilakukan oleh kantor pajak akan meningkatkan kepatuhan Wajib Pajak dalam melaporkan pendapatannya secara benar dan wajar. Peneltian ini menambahkan auditor eksternal sebagai objek penelitian dan hasil penelitian akan menjadi solusi bagi pengembangan ilmu akuntansi dan perpajakan di kemudian hari dalam memastikan bahwa pemungutan pajak dapat dioptimalkan.

\section{KESIMPULAN}

Perilaku wajib pajak (WP) pada saat pemeriksaan perpajakan dilakukan oleh auditor eksternal mengalami peningkatan kepatuhan pembayaran perpajakan. Pendekatan yang dilakukan oleh auditor eksternal dalam melakukan pemeriksaan peraturan perpajakan hotel dan restoran mampu mendorong wajib pajak melakukan pembayaran pajak. Perbedaan pendekatan yang dilakukan oleh pemerintah dengan auditor eksternal menjadi kunci bagi perilaku wajib pajak dalam melaporkan pajaknya. Auditor eksternal sukses mendorong wajib pajak untuk melaporkan omzet penjualan sesuai dengan kondisi yang sebenarnya.

Beberapa temuan yang dilaporkan oleh auditor eksternal tidak dapat ditindaklanjuti karena masalah peraturan yang tumpang tindih, seperti pembayaran zakat yang dilakukan wajib pajak yang masih dapat disubstitusikan sebagai pembayaran pajak sehingga wajib pajak mendapatkan pengurangan pembayaran pajak. Apabila auditor eksternal tidak melakukan pemeriksaan, wajib pajak kemudian kembali pada pola yang lama menyikapi ketidakkonsistenan peraturan pemerintah pusat dengan peraturan daerah. Lebih jauh lagi, ini akan menghambat stabilitas ekonomi daerah dan pembangunan berkelanjutan.

Penelitian ini memiliki beberapa keterbatasan diantaranya yaitu Pertama, luas penelitian yang terbatas pada lingkup pemerintah daerah Kabupaten Sleman dan Kotamadya Yogyakarta, hal ini dikarenakan sifat pemeriksaan yang melekat pada peraturan daerah pada lingkungan Dinas Pendapatan Pengelolaan Keuangan dan Kekayaan Aset Daerah padahal Pajak Daerah tentunya tidak dapat dipisahkan dari Peraturan Pemerintah Pusat yang berlaku. Kedua, subjek penelitian adalah auditor eksternal pada level yang kecil sehingga perlu dikembangkan pada level KAP yang lebih besar. Dalam penelitian ini penulis juga mengusulkan perlunya pemetaan data yang lebih rigid (jika memungkinkan adanya data sekunder) untuk melanjutkan perencanaan penelitian yang lebih kompleks dan terukur. 


\section{DAFTAR PUSTAKA}

Ajzen., I. (2005). Attitudes, Personality and Behavior. New York : Open University Press.

Ajzen., I. (1991). The Theory of Planned Behaviour. Organizational Behaviour and Human Decision Processes, 50, 179-211, 1991.

Anjarini, K., Prasetyo B. H., dan Irani L.D. (2012). Analisis Pelaksanaan Pemeriksaan Pajak dalam Meningkatkan Kepatuhan Wajib Pajak Orang Pribadi Pada KPP Pratama Jakarta Sawah Besar Satu. (online), (http://www.academia.edu/7651383/Jurnal_Akuntansi_Perpajakan_2012_ANA LISIS_PELAKSANAAN_PEMERIKSAAN_PAJAK_DALAM_MENINGKATKAN _KEPATUHAN_WAJIB_PAJAK_ORANG_PRIBADI_PADA_KPP_PRATAMA_J AKARTA_SAWAH_BESAR_SATU_Mahasiswa_Fakultas_Ekonomi_Universitas_ Pakuan_2, diakses pada 26 Oktober 2017).

Arini, E., (2016). Kontribusi Pajak Hotel dan Restoran terhadap PAD di Kabupaten Sleman. Tesis Magister Ekonomika Pembangunan Universitas Gadjah Mada.

Benk, S., Budak., T. (2011). An Investigation of Tax Compliance Intention: A Theory of Planned Behaviour Approach. European Journal of Economics, Finance and Administrative Science, 28, 180-188, 2011.

Creswell, J. W. (2005). Educational Research Planning, Conducting, and Evaluating Quantitative and Qualitative Research (2nd edition). New Jersey: Pearson Education, Inc.

Desai, M. A., dan Dharmapala, D. (2006).Corporate tax avoidance and high-powered incentives.Journal of Financial Economics, 79, 145-179.

Direktorat Jendral Perimbangan Keuangan. (2013). Departemen Keuangan Republik Indonesia. Pajak Daerah dan Retribusi Daerah.

Efebera, H.D., Hayes, C., Hunton, J.E., dan O'Neil, C. (2004). Tax Compliance Intentions of Low-Income Individual Taxpayers. Advances in Accounting Behavioral Research, 7, pp. 1-25.

Hartono J., (2008). Teori Portofolio dan Analisis Investasi. BPFE Universitas Gadjah Mada. Yogyakarta.

Ikatan Akuntansi Indonesia. (2002). Pernyataan Standar Akuntansi Keuangan: Kerangka Dasar Penyusunan Penyajian Laporan Keuangan. Jakarta: Salemba Empat.

Mardiasmo. (2006). Perpajakan, Jakarta : Andi.

Wahyudi N., dkk (2013). Analisis Kontribusi Pajak Daerah dalam Meningkatkan PAD Kota Padang.

Ojo, M. (2009). The Role of External Auditors in Corporate Governance: Agency Problems and the Management of Risk. Amazon Books April 2014.

Peraturan Badan Pemeriksa Keuangan Republik Indonesia No. 01 Tahun 2007. Standar Pemeriksaan Keuangan Negara.

Putri, K. (2016). Kontribusi Pajak Hotel dan Restoran terhadap PAD di Kotamadya Yogyakarta. Tesis Magister Ekonomika Pembangunan UGM.

Sarantakis, S., (1995). Social Research. Melbourne: Macmillan Education Australia Pty Ltd.

Statement on Auditing Standard (SAS). Statement on Auditing Standard No.99

Widodo, W. (2010). Moralitas, Budaya dan Kepatuhan pajak. Alfabeta, Bandung

Wirawan, I.B. (2002). Perpajakan Indonesia, Jakarta, Salemba Empat. 
Wisnu, W. P. (2016). Analisis Hubungan Partisipasi Penetapan Tujuan dan Komitmen Tujuan: Pengujian Efek Mediasi Kepercayaan Interpersonal, Keadilan Prosedural, dan Keadilan Distributif. Tesis Magister Sains UGM. 


\section{Lampiran 1. \\ Kutipan wawancara dengan auditor eksternal}

Pewawancara: Bagaimana pola perilaku wajib pajak dalam menghindari pelaporan omzet yang disyaratkan oleh peraturan? Lalu apakah dampak pemeriksaan ini dapat dirasakan untuk periode periode berikutnya?

Auditor $\quad$ : Dahulu perusahaan " $X$ " ini pernah tidak melaporkan pajak sehingga menimbulkan kurang bayar pajak yang sangat besar. Lalu setelah dilakukan pemeriksaan dan diketahui adanya kurang bayar, mereka dikenai pasal dan aturan untuk melakukan pembayaran angsuran kurang bayar selama 10 tahun. Setelah diketahuinya pajak kurang bayar tersebut, wajib pajak menjadi lebih tertib dan patuh terhadap pajak. Namun tidak menjamin bahwa perusahaan akan membayar semua pajaknya sesuai ketentuan.

Pewawancara : Jadi wajib pajak yang melakukan pelanggaran peraturan perjakan tersebut tidak memiliki laporan keuangan begitu ya pak?

Auditor : Dari 20 wajib pajak baik perorangan maupun badan yang terdaftar sebagai wajib pajak hotel dan restoran, 4 wajib pajak hotel dan 5 wajib pajak restoran dinyatakan disclaimer. Artinya, wajib pajak tersebut tidak memiliki laporan keuangan yang komprehensif sehingga tidak ada laporan perpajakan yang transparan. Wajib pajak yang dinyatakan disclaimer semuanya adalah wajib pajak perorangan.

Pewawancara: Apakah terdapat wajib pajak punya spesifikasi bisnis tertentu yang menyebabkan mereka tidak melakukan pembayaran pajak? Lalu apa penyebab dari wajib pajak tersebut melakukan pelaporan yang demikian?

Auditor : Terdapat WP pribadi jenis usaha restoran yang tidak melaporkan pajak sebagaimana mestinya karena alasan sudah melakukan pembayaran zakat, namun bukti pembayaran zakat tidak dilampirkan. Padahal WP ini memiliki omzet yang besar terhadap PAD Kabupaten Sleman. Pelaporan penjualan/omzet berbeda dengan SPT yang disampaikan ke Dinas Pendapatan Daerah. 


\section{Lampiran 2. \\ Kutipan wawancara dengan pegawai DPKKAD}

\section{Wawancara dengan responden 1}

Pewawancara: Selama ini kan pemeriksaan ini dilakukan oleh pegawai di Dinas Pendapatan Pengelolaan Keuangan dan Kekayaan Aset Daerah. Lalu apa beda yang terjadi antara pemeriksa auditor eksternal dengan pemeriksaan yang dilakukan oleh pegawai dinas?

Ibu Titin : Peran auditor eksternal dapat membantu dinas pendapatan daerah dalam pemeriksaan dan menemukan temuan kurang bayar audit. Standar dan aturan pemeriksaan merupakan pendekatan yang lain yang dilakukan oleh auditor eksternal yang membuat wajib pajak lebih patuh membayar pajak.

Pewawancara : Emangnya kalau auditor eksternal tidak melakukan audit pada tahun berikutnya apa yang terjadi?

Ibu Titin : Setelah auditor eksternal tidak melakukan pemeriksaan, perilaku wajib pajak ini kembali pada perilaku lama, yaitu tidak melaporkan semua transaksi yang seharusnya menjadi objek pajak untuk penerimaan pajak".

\section{Wawancara dengan responden 2}

Pewawancara: Apakah fungsi utama dari pemeriksaan yang dilakukan oleh auditor eksternal? Lalu wajib pajak seperti apa yang biasanya melakukan ketidakpatuhan pembayaran pajak?

BapakX : Temuan auditor eksternal mampu mengungkap ketidakwajaran laporan yang dimiliki wajib pajak pada tahun tertentu ketika pemeriksaan terhadap pajak dilakukan. Tahun berikutnya tidak lagi merupakan laporan keuangan yang tidak terpisah dari laporan hasil pemeriksaan. Hampir semua wajib pajak perorangan dinyatakan disclaimer.

Pewawancara: Apa yang dijadikan alasan oleh para wajib pajak ini untuk tidak melaporkan jumlah omzetnya? Apakah mereka tidak takut terkena sanksi yang berlaku?

Bapak X : Wajib pajak menganggap peraturan pemerintah dapat diimplementasikan ke peraturan daerah, dimana zakat merupakan objek pajak yang boleh dikurangkan dari objek pajak yang seharusnya dilaporkan. Hal ini dianggap oleh wajib pajak sebagai peluang penghindaran objek pajak sehingga wajib pajak tidak melaporkan pajak karena telah melakukan pembayaran zakat. 